\title{
Las organizaciones sobre aspectos sociales de la industria de alcoholes: Una advertencia a la salud pública
}

\section{The beverage alcohol industry's social aspects organizations: A public health warning}

\author{
Peter Anderson \\ Public Health Consultant, Eurocare \\ Enviar correspondencia: \\ Peter Anderson, PDAnderson@compuserve.com Tel. +31 243445130
}

\section{RESUMEN}

Durante los últimos veinte años, la industria alcoholera ha creado y financiado organizaciones de carácter social que le permiten controlar los problemas que pueden perjudicar sus negocios, a través de influir en las políticas del alcohol de las organizaciones gubernamentales nacionales e internacionales. Para ello se convierten en miembros de destacadas organizaciones específicamente anti-alcohol y de comités que tienen influencia política y respetabilidad; reclutan científicos, organizan congresos y promocionan publicaciones de alto nivel; crean organizaciones de carácter social en mercados emergentes y en países de renta per cápita baja; y preparan y promocionan declaraciones de consenso y códigos de práctica.

Estas organizaciones de carácter social apoyan criterios básicos que, al ser analizados, confirman que su objetivo global no es beneficiar a la salud y al bienestar públicos, sino a la propia industria alcoholera como pueden ser que se puede aprender a beber de forma responsable como base de la prevención, pero si no se tiene en cuenta el entorno social en que el alcohol se consume (políticas de precio, disponibilidad y marketing de los productos alcohólicos, etc) las políticas del alcohol basadas en la responsabilidad individual son ineficaces para reducir los daños que éste ocasiona.

El planteamiento de que el marketing de las bebidas alcohólicas debería estar regulado por la propia industria de bebidas alcohólicas no puede funcionar pues la industria ha roto sus propios códigos de un modo patente, constante y extensivo en todos los lugares del mundo, sin que exista la menor evidencia de que esto haya mejorado en los últimos años.

Palabras clave: alcohol, prevención, políticas, salud pública, industria.

\section{ABSTRACT}

Over the last twenty years the beverage alcohol industry has set up and funded social aspects organizations to manage issues that may be detrimental to its business. They aim to manage issues by: attempting to influence the alcohol policies of national and international governmental organizations; becoming members of relevant non-alcohol specific organizations and committees to broaden policy influence and respectability; recruiting scientists, hosting conferences and promoting high profile publications; creating social aspects organizations in emerging markets and low income countries; and preparing and promoting consensus statements and codes of practice.

Social aspects organizations hold viewpoints which on inspection confirm their overall aim, which is to benefit their funding body, the beverage alcohol industry, rather than to benefit public health or the public good.

For example, the view that responsible drinking can be learned and that this should be the cornerstone of alcohol policy fails to recognize that without addressing the social environment in which the alcohol is consumed (including policy on the price, availability and marketing of alcohol products) alcohol policies based on individual responsibility are ineffective in reducing harm.

Another example is the view that the marketing of alcoholic beverages should be regulated by the beverage alcohol industry itself is inherently unlikely to work, since the essence of selfregulation is that compliance with codes is voluntary and the industry has blatantly, consistently and extensively broken its own codes in all areas of the world, with no evidence that this has improved over recent years.

Key words: alcohol, prevention, policies, Public health, alcohol industry. 


\section{INTRODUCCIÓN}

A lo largo de los últimos veinte años la industria de bebidas alcohólicas ha creado y financiado organizaciones de carácter social para representar a la industria en el debate político sobre el alcohol y en el discurso social y público sobre el daño ocasionado por éste. Las organizaciones de carácter social operan a nivel internacional (International Center for Alcohol Policies, http://www.icap.org), a nivel europeo (The Amsterdam Group, www.amsterdamgroup.org.), a nivel nacional (por ejemplo, la Fundación para el Alcohol y la Sociedad en España www.alcoholysociedad.org.), y en países de renta alta, media y baja.

Aunque en apariencia actúan con intención de beneficiar o mejorar la condición de la sociedad, debería recordarse que el planteamiento principal de la industria de bebidas alcohólicas es maximizar sus ganancias (1): Todas las acciones llevadas a cabo por la dirección van dirigidas a conseguir un objetivo primordial: aumentar el valor de las acciones".

Con estas organizaciones de carácter social, la industria de bebidas alcohólicas ha pretendido crear la imagen de un negocio implicado en lo social, mientras que, al mismo tiempo, trata de difundir críticas y manipular el debate público en una serie de problemas que afectan a su negocio. Entre las cuestiones que la industria de las bebidas alcohólicas quisiera controlar se encuentran las políticas de alcohol eficaces para reducir el daño, tales como los impuestos, las limitaciones y la disponibilidad de las bebidas alcohólicas, frases como 'el daño ocasionado por el alcohol', y prácticas de marketing en países de baja renta y de población joven.

Las organizaciones de carácter social intentan controlar los problemas que se les plantean consiguiendo estar representados en una amplia gama de organizaciones nacionales e internacionales, gubernamentales y no gubernamentales (2); trabajando con funcionarios públicos para dictar normas que legitimicen sus prácticas y sus oportunidades de marketing; desviando la atención pública y la controversia hacia asuntos de importancia secundaria; patrocinando a respetables catedráticos para que realicen investigaciones cuya agenda define la industria de las bebidas alcohólicas; buscando nuevos enfoques en la controversia, iniciando diálogos con el público necesarios para mantener la viabilidad de la industria; invitando a defensores cuidadosamente seleccionados y a críticos a participar en diálogos orientados al consenso, para después utilizar su participación para mejorar la imagen de su propia industria; $y$, finalmente, desacreditando a los críticos con etiquetas estereotipadas, tales como anti-alcohol, anti-negocio o prohibicionista.

Mientras que para sectores gubernamentales y no gubernamentales, y para corporaciones científicas, profesionales y educativas puede resultar muy sugestivo

\section{INTRODUCTION}

$\mathbf{0}$ ver the last twenty years the beverage alcohol industry has set up and funded social aspects organizations to represent the industry in the alcohol policy debate and in the social and public discourse about the harm done by alcohol. Social aspects organizations operate at the global level (International Center for Alcohol Policies, http: //www.icap.org), the European level (The Amsterdam Group, www.amsterdamgroup.org), and at the country level (for example, The Alcohol and Society Foundation in Spain www.alcoholysciedad.org.) in high, middle and low income countries.

Although apparently acting with a view to benefit or improve the condition of society, it should be remembered that the beverage alcohol industry's primary focus is to maximize profits (1): "Every action taken by management is guided by one overriding objective - enhancing shareholder value."

In setting up social aspects organizations the beverage alcohol industry has aimed to create an image of a socially concerned business, whilst at the same time attempting to diffuse criticism and to manage public debate on issues that are sensitive to its business. Among the issues that the beverage alcohol industry would like to manage are alcohol policies that are effective in reducing harm, such as taxation and limitations on the availability of beverage alcohol, phrases such as 'the harm done by alcohol', and marketing practices in low income countries and to young people.

Social aspects organizations attempt to manage issues by gaining representation in a wide range of national and international governmental and non-governmental organizations (2); by working with national and international civil servants to create regulations that legitimize their marketing practices and opportunities; by diverting public attention and controversy through focusing on issues of secondary importance; by sponsorship of respected academics to engage in research whose agenda is specified by the beverage alcohol industry; by refocusing public controversy by initiating dialogues with the public that are needed to sustain industry viability; by inviting carefully selected supporters and critics to participate in consensus-orientated dialogues and then using their participation to enhance the image of their own industry; and by discrediting critics by stereotyping them with such labels as anti-alcohol, anti-business or prohibitionist.

Whilst it may be very appealing for governmental and non-governmental sectors and for educational, professional and scientific bodies to partner with the beverage alcohol industry through its social aspects 
asociarse a la industria de las bebidas alcohólicas a través de sus organizaciones de carácter social, no debe olvidarse que éstas no son imparciales. Estas asociaciones pueden comprometer la independencia de la salud pública, con riesgo de perjudicar el bien público y de producir una gran desconfianza de la sociedad civil en sus instituciones públicas. Sería preciso asegurar un alto nivel de protección de la salud a través de la definición e implementación de las políticas y actividades gubernamentales. Los datos científicos deberían tener más peso en la formulación de las políticas de salud pública sobre el alcohol que los defendidos por la industria de las bebidas alcohólicas. Desgraciadamente, no siempre ocurre así.

\section{¿CON QUÉ FINALIDAD EXISTEN ESTAS ORGANIZA- CIONES DE CARÁCTER SOCIAL?}

Cinco criterios expuestos por las organizaciones de carácter social confirman su principal objetivo: obtener beneficios para la industria de las bebidas alcohólicas más que favorecer la salud y el bien públicos.

\section{Primer criterio - responsabilidad individual}

La noción de responsabilidad individual propuesta por las organizaciones de carácter social, y las consecuentes opciones políticas basadas en el individuo que ellas (3) apoyan, ignoran el entorno en el que se consume el alcohol, y se sitúan de ese modo lejos de poder reducir el daño ocasionado por el alcohol.

Para el individuo que bebe, el daño producido por el alcohol está relacionado con ambas cosas, el volumen del alcohol consumido, y el modo en que éste se ha consumido (4). En casi todos los estados físicos relacionados con el alcohol, incluyendo la cirrosis hepática y los cánceres relacionados con el consumo de alcohol, el nivel de consumo de alcohol es más determinante del daño que el modo en que éste se consume. El riesgo aumenta a medida que aumentan los niveles de consumo de alcohol, y no existe un punto de separación claro entre consumo, consumo peligroso y consumo perjudicial. En cuanto a los estados producidos por intoxicaciones de alcohol (incluyendo accidentes, accidentes de tráfico, violencia intencionada contra uno mismo o contra los demás, suicidio, violencia familiar, crimen con violencia, comportamiento criminal, y trato injusto, incluyendo robo y rapto), tanto el nivel de alcohol consumido como el modo en que se consume están relacionados con el riesgo de daños. El riesgo aumenta con niveles más elevados de consumo y está influido por diferentes pautas en la bebida.

A nivel social, existe una relación directa entre los niveles de consumo per capita y el daño ocasionado por el alcohol. En el Estudio Europeo Comparativo de Alco- organizations, it should be remembered that these organizations are not impartial. Such partnerships can compromise the independence of public health with a risk of damaging the public good and of impairing the trust of civil society in its public institutions. A high level of human health protection should be ensured in the definition and implementation of governmental policies and activities. Science based evidence should carry greater weight in the formulation of public health policies concerning alcohol than that of the special pleading of the beverage alcohol industry. Unfortunately, this does not often happen.

\section{WHAT DO SOCIAL ASPECTS ORGANIZATIONS STAND FOR?}

Five standpoints advanced by social aspects organizations confirm their overall aim, which is to benefit their funding body, the beverage alcohol industry, rather than to benefit public health or the public good.

\section{Standpoint one - individual responsibility}

The notion of individual responsibility put forward by the social aspects organizations and the consequent individual based policy options favoured by them (3) ignore the social environment in which the use of alcohol takes place and are thus positioned to fail in reducing the harm done by alcohol.

For the individual drinker, the harm done by alcohol is related to both the volume of alcohol consumed and to how the alcohol is consumed (4). For almost all of the physical conditions related to alcohol, including cirrhosis of the liver and alcohol-related cancers, the level of alcohol consumption is a more important determinant of harm than how the alcohol is consumed. The risk of these conditions increases with increasing levels of alcohol consumption, and there is no clear cut off point between use, hazardous use and harmful use. For conditions related to alcohol intoxication, (including accidents, road traffic accidents, intentional violence both towards self and others, suicide, family violence, violent crime, engaging in criminal behaviour, and victimization, including robbery and rape) both the level of alcohol consumed and how it is consumed are related to the risk of harm. For these conditions, the risk increases with increasing levels of alcohol consumption and is influenced by different patterns of drinking.

At the societal level, there is a direct relationship between levels of per capita consumption and alcohol related harm. The European Comparative Alcohol Study reviewed the post-war experience of alcohol 
hol (European Comparative Alcohol Study) se analizó la experiencia posguerra del alcohol y la mortalidad en los países de la Unión Europea (5). Unos análisis de series temporales demostraron que existe una relación positiva y significativa entre los cambios en el consumo de alcohol y los cambios en la mortandad general de hombres y mujeres relacionada con el alcohol. La relación es aplicable al daño producido por todo tipo de bebidas alcohólicas, y es más acusada en países con un consumo general de alcohol más bajo que en países con un consumo general más alto. Por ejemplo, un litro extra de alcohol por persona derivaría en un aumento del 12.4\% de homicidios en el Norte de Europa, pero sólo en un $5.5 \%$ en la Europa meridional.

Las organizaciones de carácter social presuponen que la responsabilidad individual debería ser la esencia de la política del alcohol. Emplean el término 'abuso', que implica el uso irresponsable del producto de la industria de bebidas alcohólicas y que es la causa de que resulte perjudicial. Dan a entender que el bebedor individual es el responsable de abusar o no abusar del producto. La Organización Mundial de la Salud ha considerado el término 'abuso' potencialmente peyorativo y emocionalmente cargado, y ha dejado de emplearlo por considerarlo ambiguo en su clasificación ICD10 sobre trastornos mentales y de comportamiento al referirse a drogas que crean dependencia (6). Los términos intoxicación, consumo perjudicial y adicción tienen preferencia.

Los enfoques que se centran en la responsabilidad individual y en el cambio individual no tienen en cuenta los factores sociales que gobiernan la conducta, incluyendo varios imperativos ambientales y las presiones que limitan la elección individual. Las estrategias basadas en el individuo son bastante menos eficaces que las estrategias dirigidas a controlar o alterar factores importantes dentro del entorno inmediato del individuo, tales como la disponibilidad física o económica del alcohol, serios controles sociales de los comportamientos relacionados con el alcohol, e iniciativas encaminadas a cambiar las prácticas relacionadas con el alcohol en los ambientes donde se bebe a través de importantes medidas para la comunidad. Una política eficaz para reducir los daños causados por el alcohol debe determinar el entorno donde se bebe, para permitir que las elecciones más sanas sean las más fáciles.

\section{Segundo criterio - cambiar el ambiente que rodea a la bebida}

La financiación y puesta en práctica de programas educativos por estas organizaciones de carácter social crea un conflicto de intereses, y todos estos programas se vinculan con demasiada facilidad a campañas de marketing para consumir los productos de la industria de bebidas alcohólicas.

El quinto libro del 'International Center for Alcohol Policy's Series on Alcohol and Society' se titula Learning and mortality in the countries of the European Union (5). Time series analysis demonstrated that there is a positive and significant relationship between changes in alcohol consumption and changes in both overall and alcohol related death for both men and women. The relationship applies to all types of alcohol related harm, and is stronger in countries with lower overall alcohol consumption than in countries with higher overall alcohol consumption. For example, an extra litre of alcohol per person would result in a $12.4 \%$ increase in homicides in northern Europe, but only a $5.5 \%$ increase in southern Europe.

Social aspects organizations imply that individual responsibility should be at the core of alcohol policy. They use the term abuse, implying that this is an irresponsible use of the beverage alcohol industry's product and is the cause of harm. They imply that it is the individual drinker who is responsible for whether or not the product is abused. The World Health Organization has considered the term abuse as potentially pejorative and emotionally laden, and because of its ambiguity no longer uses it in its ICD 10 classification of mental and behavioural disorders when referring to drugs of dependence (6). The terms intoxication, harmful use and dependence take preference.

Approaches centred on individual responsibility and individual change fail to consider the social factors governing behaviour, including the various environmental constraints and pressures that limit individual choice. Individual based strategies are far less effective than strategies aimed at controlling or altering relevant factors within the individual's immediate environment, such as the physical and economic availability of alcohol, formal social controls on alcohol-related behaviour and initiatives aimed at changing alcohol-related practices in the drinking environment through broad-based community action. Effective policy to reduce the harm done by alcohol is about shaping the individual's drinking environment to enable the healthy choices to be the easy choices.

\section{Standpoint two - changing the climate around drinking}

The funding and implementation of educational programmes by social aspects organizations creates a conflict of interest, and such programmes all too easily merge into marketing campaigns for the use of the beverage alcohol industry's products.

The fifth book in the International Center for Alcohol Policy's Series on Alcohol and Society is Learning about Drinking (7). The publication advanced the standpoint that drinking is a learned behaviour, much like learning to drive. It is proposed that if what influences this learning is better understood programs 
about Drinking (7). La publicación sustenta el criterio de que beber es un comportamiento aprendido, muy parecido a aprender a conducir. Propone que si lo que ejerce influencia en este aprendizaje es mejor comprendido, los programas que tratan de reducir el daño serán probablemente más eficaces. Las organizaciones de carácter social ponen en práctica y consolidan una serie de programas para respaldar su interpretación de estilos de vida responsables, incluyendo, por ejemplo, programas de educación en la escuela y campañas "de conductores designados" destinadas a reducir el consumo de alcohol cuando se conduce.

En países de baja renta per capita, el Centro Internacional para Políticas del Alcohol ha promocionado el aprendizaje del consumo de bebidas alcohólicas a través de su programa 'Growing Up Life Skills Education' (8), impartidos en los siete cursos de primaria de varios colegios seleccionados en África del Sur y en Botswana durante el período de 1996-1999. El programa incluía los problemas relacionados con el consumo de alcohol, pero no se centraba en ellos.

Se ha demostrado que, aunque ciertas iniciativas en el período escolar pueden cambiar el conocimiento y las actitudes con respecto al alcohol, éstas son generalmente ineficaces y no modifican el comportamiento en el consumo del alcohol ni previenen el daño ocasionado por éste. Esto, sin embargo, no es sorprendente, pues la educación de la escuela compite con una barrera de mensajes que fomentan el consumo del alcohol. La fuente principal de los mensajes pro-alcohol es la realidad social en sí misma, la disponibilidad tan extendida y evidente de bebidas alcohólicas, y la presencia y aceptación del alcohol en toda clase de situaciones y contextos de la vida diaria. La influencia de la experiencia en la concepción que la gente tiene de las cuestiones relacionadas con el alcohol tiende a ser más poderosa que cualquier información suministrada sobre el alcohol.

Lamentablemente, se ha investigado muy poco sobre la efectividad de las campañas "de conductores designados", apoyadas por las organizaciones de carácter social para reducir los accidentes de tráfico relacionados con el alcohol $(9,10)$. Con la escasa información disponible, parece que estas campañas son en gran medida ineficaces y, desde luego, no tan efectivas para prevenir accidentes de tráfico relacionados con el alcohol como se pretendía en un principio (11). Muchos de los que aceptan ser conductores, se vuelven atrás después de beber, aunque ello signifique aceptar su condición de conductores que abusan del alcohol. Además, existe cierta evidencia de que la presencia de un 'conductor designado' anima a los que no conducen a beber más de lo que harían en otras ocasiones, poniéndose en mayor peligro si ellos o los conductores elegidos cambian de idea. Desgraciadamente, las organizaciones de carácter social normalmente se oponen a iniciativas tales como reducir los niveles de concentración de alcohol en sangre permitidos a los conductores (BAC) o la that seek to reduce harm are likely to be more effective. Social aspects organizations implement and fund a number of programmes to support their understanding of responsible lifestyles, including, for example, educational programmes at school and designated driver campaigns to reduce drink driving.

In low income countries, the International Center for Alcohol Policies has promoted learning about drinking through its Growing Up Life Skills Education programme (8), which was developed for all seven grades of selected primary schools in South Africa and Botswana, during the period from 1996-1999. The program included, but did not focus primarily upon, issues related to beverage alcohol.

The evidence is that whilst school-based educational initiatives can change knowledge and attitudes about alcohol, they are generally ineffective in changing behaviour in the use of alcohol or preventing the harm done by alcohol. This is hardly surprising since school-based education competes against a barrage of messages that promote the use of alcohol. The primary source of pro-alcohol messages is social reality itself, the widespread and visible availability of alcoholic beverages, and the presence and acceptability of alcohol in a variety of everyday situations and contexts. The influence of experience on people's conceptions of alcohol issues tends to be more powerful than that of any alcohol information provided.

Unfortunately, there has been very little research to test the effectiveness of the designated driver campaigns that are supported by the social aspects organizations to reduce alcohol-related traffic accidents $(9,10)$. From the limited evidence that is available, it appears that designated driver campaigns are largely ineffective and certainly not as effective as a measure to prevent alcohol-related traffic accidents as originally envisioned (11). Many who agree to serve as designated drivers renege after drinking, even though it means becoming an intoxicated driver. Further, there is some evidence that the presence of a designated driver encourages the non-drivers to drink more than they would otherwise, making them a greater danger if either they or the designated drivers changed their minds. Unfortunately, the social aspects organizations are generally opposed to those initiatives, such as reducing blood alcohol concentration (BAC) levels permitted for driving or high visibility random breath testing that have been demonstrated to be effective in saving deaths from alcohol related road traffic accidents.

Education on alcohol is one aspect of public communication, which is connected with alcohol advertising and other media representations of alcohol (12). Although education as a means of reducing the harm done by alcohol has limited success, this does not mean, however, that com- 
prueba de alcoholemia en conductores elegidos al azar, que han demostrado ser muy eficaces a la hora de salvar vidas, al reducir los accidentes de tráfico.

La educación sobre el alcohol es un aspecto de los medios de comunicación públicos, conectado con la publicidad y otras representaciones del alcohol en los medios de información (12). A pesar de que la educación como medio para reducir el daño producido por el alcohol tiene un éxito limitado, esto no significa que la información sobre el alcohol no juegue un papel primordial en la formación de creencias y de percepciones. Como el alcance de la experiencia directa con el alcohol es limitada en la mayoría de las personas, muchas de sus ideas y nociones se basan en lo que han aprendido de otras personas o en los medios de comunicación. Éstos emiten un constante flujo de imágenes e impresiones sobre el alcohol y la bebida. Estas imágenes presentan, sobre todo, el consumo del alcohol como una práctica inofensiva, y restan importancia a los riesgos potenciales para la salud y otras consecuencias negativas. Cuando los medios describen consecuencias negativas para la sociedad, para la economía o para la salud, tienden a presentar estos males como ocasionales y no como riesgos inherentes al consumo del alcohol. No es sorprendente, por ese motivo, que las iniciativas educativas apenas tengan éxito a la hora de conseguir cambios de comportamiento dirigidos a reducir el daño ocasionado por el alcohol. Se encuentran, sencillamente, ahogadas por el flujo masivo de mensajes que refuerzan la aceptabilidad social del alcohol y el alto nivel de prevalencia de su consumo. Un gran número de estos mensajes son anuncios comerciales que describen el consumo del alcohol como un componente esencial en un estilo de vida deseable. Cuando la educación sobre el alcohol financiada y puesta en práctica por la industria de las bebidas alcohólicas es contemplada dentro de este contexto, es difícil evitar que se desdibujen los límites entre la educación, la publicidad y la visión que dan los medios de comunicación sobre el consumo del alcohol.

Se estima que las áreas de expansión del consumo de bebidas alcohólicas son los mismos mercados emergentes de los que se habla en el segundo volumen del International Center for Policies Series on Alcohol and Society, titulado Alcohol and Emerging Markets (13), es decir, Asia, Europa Central, Europa del Este, América Latina y Africa subsahariana. El Centro Internacional para las Políticas de Alcohol (14) está promocionando activamente lo que denomina 'políticas de alcohol equilibradas basadas en asociaciones entre sectores públicos y privados' en una serie de países con renta per cápita baja y mercados emergentes, introduciendo 'conceptos de bebida responsable en países donde el alcohol no es necesariamente una parte tradicional de su cultura'. El compromiso de las organizaciones de carácter social con los mercados emergentes y con los países de renta per cápita baja puede interpretarse como una herramienta de marketing que refleja una evidente falta de munication about alcohol plays no role in shaping people's beliefs and perceptions. As the range of most people's direct experience with alcohol is limited, many of people's views and notions are based on what is learnt from other people or from the mass media. The media convey a steady flow of images and views on alcohol and drinking. These images mainly represent alcohol consumption as a harmless practice, playing down the potential health risks and other negative consequences. When the media do depict negative social, economic or health consequences, they tend to present these as occasional afflictions rather than as risks inherent in alcohol use. It is not surprising, therefore, that educational initiatives rarely succeed in bringing about behavioural change in the direction of reducing the harm done by alcohol. They are simply swamped by the massive flow of messages conveying the social acceptability and high level of prevalence of alcohol use. A large part of these messages are commercial advertisements that portray the use of alcohol as an essential component of desirable lifestyles. When alcohol education funded and implemented by the beverage alcohol industry is viewed within this context, it is very difficult to avoid the blurring between education, advertising and the media portrayal of the use of alcohol.

It is estimated that the growth areas for the use of alcoholic beverages are the same emerging markets that are considered in the second volume of the International Center for Alcohol Policies' Series on Alcohol and Society, Alcohol and Emerging Markets (13), that is Asia, Central and Eastern Europe, Latin America and sub-Saharan Africa. The International Center for Alcohol Policies (14) is actively promoting what it calls 'balanced alcohol policies based on partnerships between the public and private sectors' in a number of low income countries and emerging markets, introducing the 'concepts of responsible drinking in countries where drinking is not necessarily a traditional part of the culture'. The involvement of social aspects organizations in emerging markets and low income countries can be understood as a marketing tool which shows little respect for the vast majority of individuals in such countries who choose not to consume alcohol, and with little regard for the harm that alcohol can add to the problems of already impoverished individuals, families and communities (15).

\section{Standpoint three - a place at the policy table}

The common language the International Center for Alcohol Policies promotes is pleasure, the social aspects organizations' brand and means of policy influence, and the theme of the Center's third book in 
respeto hacia la inmensa mayoría de los individuos que en esos países eligen no consumir alcohol, y pretende ignorar los daños que el alcohol puede añadir a los problemas de los ya empobrecidos individuos, sus familias y comunidades (15).

\section{Tercer criterio - un lugar en el marco político}

El lenguaje habitual que promueve el Centro Internacional para las Políticas del Alcohol es el del placer, las marcas y medios de influencia política de las organizaciones de carácter social, y el tema del tercer libro en sus series acerca del Alcohol y la Sociedad, Alcohol and Pleasure: a Health Perspective (16).

Existe un único problema en este planteamiento: las organizaciones de carácter social no son ni organismos de salud pública ni organizaciones científicas, sino organizaciones de la industria de bebidas alcohólicas que desvirtúan los datos básicos para una política eficaz que reduzca el daño ocasionado por el alcohol (17). En general, las opciones políticas que han demostrado ser eficaces en la reducción del daño ocasionado por el alcohol no se hallan sustentadas por las organizaciones de carácter social, en tanto que las opciones políticas que han demostrado ser ineficaces para reducir el daño ocasionado por el alcohol (u opciones políticas de las que no tenemos datos) sí están apoyadas por dichas organizaciones.

\section{Cuarto criterio - autorregulación de la industria}

Las organizaciones de carácter social sostienen que no existen suficientes pruebas que evidencien la asociación entre publicidad y niveles o pautas de consumo de alcohol. Se oponen a las restricciones legislativas de la comercialización de bebidas alcohólicas y creen que ésta debería ser regulada por la propia industria de bebidas alcohólicas .

Los miembros de las organizaciones de carácter social de la industria de bebidas alcohólicas han roto continuamente sus propios códigos de publicidad (18) en todas las partes del mundo, y no existe la menor prueba de que esto haya cambiado en los últimos años.

La autorregulación tiene de por sí pocas probabilidades de éxito, pues su esencia en la mayoría de los países y de los medios de comunicación es que el seguimiento de los códigos es voluntario, y está sujeto a cambios y revisiones de la propia industria de bebidas alcohólicas (19). En teoría, un código voluntario puede ser controlado por organizaciones públicas y no-gubernamentales, pero la eficacia dependerá de un extenso conocimiento del código, un cuerpo de reclamaciones suficientemente independiente con poder para sancionar, y fondos suficientes para controlar las prácticas del marketing y poner en ejecución litigios si ello se hace necesario. La mayoría de las campañas de publicidad están diseñadas como cortas ráfagas para evitar efectos its Series on Alcohol and Society, Alcohol and Pleasure: a Health perspective (16).

There is simply one problem with this approach: social aspects organizations are neither public health bodies nor scientific organizations, but beverage alcohol industry organizations which misrepresent the evidence base for effective policy to reduce the harm done by alcohol (17). In general, policy options that have been demonstrated to be effective in reducing the harm done by alcohol are not supported by the social aspects organizations, whereas policy options that have been demonstrated to be ineffective in reducing the harm done by alcohol (or policy options for which there is no evidence either way) are supported by the social aspects organizations.

\section{Standpoint four - industry self-regulation}

The social aspects organizations take the view that there is insufficient evidence to support an association between advertising and levels or patterns of drinking. They are opposed to legislative marketing restrictions and believe that the marketing of alcoholic products should be regulated by the beverage alcohol industry itself.

The beverage alcohol industry members of the social aspects organizations have blatantly, consistently and extensively broken their own advertising codes in all areas of the world (18) and there is no evidence that this has changed over recent years.

Self-regulation is inherently unlikely to work, since the essence of self-regulation in most countries and in most media is that compliance with codes is voluntary, and subject to changes and revision by the beverage alcohol industry itself (19). In theory, a voluntary code can be monitored by the public and non-governmental organizations, but the effectiveness of this will depend on widespread knowledge of the code, a sufficiently independent complaints body with powers of sanction, and sufficient funds to monitor marketing practices and implement litigation if necessary. Most advertising campaigns are designed as short bursts to avoid saturation effects, so complaints decisions must be fast. "Pre-vetting" may increase effectiveness, but beverage alcohol industry self-regulation against its own interests not infrequently leads to under-regulation and underenforcement. Bodies that judge adherence to the codes tend to restrict their judgements to the intentions of the advertisers, rather than to the real effects of the advertisements on, for example, young people, even when the evidence shows that young people perceive the advertisements as being directed at them (20). 
de saturación, de modo que las reclamaciones deben ser inmediatas. Investigar previamente puede aumentar la eficacia, pero la autorregulación de la industria de bebidas alcohólicas en contra de sus propios intereses lleva a menudo a la regulación y aplicación insuficiente de las medidas. Los organismos que juzgan la adhesión a los códigos tienden a limitar sus juicios a las intenciones de los anunciantes, más que a los efectos reales de los anuncios en, por ejemplo, gente joven, incluso cuando es ostensible que los jóvenes perciben los anuncios como especialmente dirigidos a ellos (20).

A nivel individual, dos análisis de datos longitudinales han hallado un impacto de respuesta a los anuncios sobre el consumo de alcohol en Nueva Zelanda (21). En el primero, los números de los anuncios sobre alcohol citados a la edad de quince años en respuesta a una pregunta sobre la visión del alcohol en los medios, pronosticaban un reforzamiento de la bebida en los jóvenes de 18 años. En el segundo análisis, el impacto positivo de la publicidad en los jóvenes de 18 años preconizaba un aumento en el consumo de alcohol y más problemas relacionados con el alcohol a la edad de 21 años.

Un estudio irlandés demostró que la publicidad del alcohol tiene un gran poder de atracción sobre los jóvenes adolescentes, al representar estilos de vida e imágenes que forman parte de su entorno social (22). La mayoría creía que los anuncios iban dirigidos a los jóvenes, de igual modo que los que representaban lugares de baile, clubbing, música viva y actividades de riesgo, que ellos consideraban sinónimo de sus actividades sociales. Lo que el grupo más joven (12-14 años) percibía en los mensajes publicitarios era que el alcohol podía ayudarles a pasarlo muy bien, a hacer muchos amigos y a ganar popularidad y que, los que no bebían, se perdían todo eso. El mensaje que captaba el grupo de 15-17 años era que el éxito social y la diversión eran consecuencia de beber alcohol.

\section{Quinto criterio - eliminación de pautas de bebida negativas}

A la industria de bebidas alcohólicas no le interesa desde el punto de vista económico eliminar las pautas de bebida negativas. La industria obtiene beneficios de las pautas de bebida negativas. Si las organizaciones de carácter social tuvieran éxito en sus objetivos eliminando pautas de bebida negativas, lo que harían es reducir las ganancias de sus patrocinadores.

Alcohol and Pleasure: a Health perspective, el tercer libro del "International Center for Alcohol Policies' Series on Alcohol and Society" fomenta la visión de que, para la mayoría de las personas, el alcohol ofrece grandes ventajas, a pesar de conlleva algunos riesgos (23). El cuarto libro de la serie, Drinking occasions: Comparative Perspectives on Alcohol and Culture, expone, en un análisis antropológico de los hábitos comparativos entre los bebedores, que la mayoría de las ocasiones en las que
At the individual level, two analyses of longitudinal data have found an impact of response to advertising on consumption in New Zealand (21). In the first, the numbers of alcohol advertisements recalled at age 15 years in response to a question about the portrayal of alcohol in the media significantly predicted heavier drinking among young men aged 18 years. In the second analysis, liking for advertising measured at age 18 years predicted heavier drinking and experience of more alcohol-related problems at age 21 years.

An Irish study found that that alcohol advertising has a strong attraction for teenagers, as it portrays lifestyles and images which are part of their social setting (22). Most believed that the alcohol advertisements were targeted at young people as the advertisements depicted dancing, clubbing, lively music and wild risqué activities which they consider synonymous with their social activities. The younger age group (12-14 years) perceived the advertising messages as saying that alcohol can help them have fun, make friends and become popular and those that don't drink are missing out. The message from the alcohol advertisements for the older age group (15-17 years) was that social success and a good time results from alcohol use.

\section{Standpoint five - elimination of negative drinking patterns}

It is not in the beverage alcohol industry's economical interests to eliminate negative drinking patterns. The industry makes its profits from negative drinking patterns. If social aspects organizations were successful in their objectives in eliminating negative drinking patterns they would substantially minimize the profits of their sponsors.

Alcohol and Pleasure: a Health perspective, the third book in the International Center for Alcohol Policies' Series on Alcohol and Society, promoted the view that for most people most of the time alcohol can confer considerable benefits, although it carries some risks (23). The fourth book in the Series, Drinking occasions: Comparative Perspectives on Alcohol and Culture, an anthropological review of global drinking habits, put forward the view that most drinking occasions are normal parts of daily life and not associated with problems or excess (24).

Whilst the social aspects organizations propose that their objectives are to promote moderate and responsible drinking, it should be remembered that alcohol is essentially an intoxicating and dependence producing drug (25). It is drunk for its intoxicating effects, even by those who are light or moderate consumers of wine. Many drinkers, and in particular younger men, deliberately and self-consciously use 
se consume alcohol forman parte de la vida cotidiana y no van asociadas a problemas ni excesos (24).

Mientras las organizaciones de carácter social plantean que sus objetivos son promocionar la bebida moderada y responsable, debería recordarse que el alcohol es esencialmente una droga que produce intoxicación y dependencia (25).

Los individuos lo beben por sus efectos embriagadores, incluso aquellos que son consumidores de vino moderados. Muchos bebedores, en particular los más jóvenes, consumen alcohol buscando de forma deliberada y consciente la intoxicación, es decir, emborracharse. De modo que los beneficios de la moderación en la bebida se producen a pesar de, y no debido a, la naturaleza de la droga. La industria de bebidas alcohólicas es consciente de los efectos embriagadores del alcohol. Un análisis de la publicidad sobre alcohol dirigida especialmente a jóvenes, nos muestra, que su capacidad para embriagar, y el atractivo y excitación asociados a este estado, son el punto clave para la venta del producto. Un pequeño porcentaje de la población es responsable de una cantidad enormemente desproporcionada del total del alcohol consumido. El 10\% de la población puede consumir entre un $30 \%$ y un $60 \%$ de la cantidad total consumida en sociedad (26). Así, pues, si todos los bebedores peligrosos y todos los bebedores que habitualmente consumen por encima de los niveles recomendados médicamente se transformaran en bebedores moderados o responsables, los beneficios de la industria de bebidas alcohólicas se verían considerablemente mermados.

El consumo del alcohol causa un daño importante en la salud física, psicológica y social de individuos, familias y comunidades, tanto en países de renta per cápita alta como baja. Se estima que explica el $4 \%$ de los años de discapacidad (disability-adjusted life years, DALYs) perdidos en el año 2000 (27). Es un factor de riesgo para la salud global, situado al mismo nivel que el sarampión, la tuberculosis y la malaria juntos.

En las estimaciones de placer y de una vida larga y sana se pone mucho énfasis en los efectos cardio-protectores del alcohol. Aunque existe la evidencia de que el consumo en niveles tan bajos como una sola toma de alcohol a la semana puede ofrecer algún grado de protección contra las enfermedades coronarias, es un hecho que viene casi siempre de países de renta per cápita alta, donde ha habido un debate considerable acerca del alcance de la reducción en el riesgo (28). Puesto que las enfermedades coronarias afectan sobre todo a hombres mayores de 35 años y a mujeres postmenopáusicas, el efecto se ha limitado a grupos de edad avanzada. Sin embargo, mientras numerosos estudios han hallado algún efecto, otros no lo han hecho, y los primeros podrían haber cometido fallos metodológicos. Una vida larga y sana entre los que consumen pequeñas cantidades de alcohol puede también ser alcohol to pursue intoxication, i.e. to get drunk. Thus the benefits of moderate drinking occur in spite of, not because of, the basic nature of the substance. The beverage alcohol industry is aware of alcohol's intoxicating effects. An examination of alcohol advertising especially that aimed at young people shows that its ability to intoxicate, and the glamour and excitement with which intoxication is associated is the product's main selling point. A small percentage of the population is responsible for a greatly disproportionate amount of the total alcohol consumed. Ten per cent of the population may consume between $30 \%$ and $60 \%$ of the total amount consumed in a society (26). Thus if all hazardous drinkers and drinkers currently drinking above medically recommended levels were somehow transformed into moderate or responsible drinkers, the beverage alcohol industry's profits would be considerably diminshed.

Alcohol use causes significant harm to the physical, psychological and social health of individuals, families and communities in both high and low income countries. It was estimated to account for $4 \%$ of the disability-adjusted life years (DALYs) lost in the year 2000 (27). It is a risk factor to global health on the same level as measles, tuberculosis and malaria combined.

In the estimates of pleasure and a long and healthy life, much emphasis is placed on the cardioprotective effects of alcohol. Although there is evidence that alcohol use at levels as low as one drink per week may offer some degree of protection against coronary heart disease, it is an effect reported mostly from high income countries, where there has been considerable debate on the size of the reduction in risk (28). Since coronary heart disease primarily affects men aged over 35 years and postmenopausal women, the effect has been primarily confined to older age groups. However, while numerous studies have found an effect, several have not, and the former may have had methodological failings. A long and healthy life amongst those who consume small amounts of alcohol may well be due to other factors, such as a healthier diet, greater physical activity and less cigarette smoking (29).

\section{Relating to social aspects organizations}

In representing the beverage alcohol industry in policy debate and in social and public discourse about the harm done by alcohol, the social aspects organizations will seek partnerships and joint activities with governmental and non-governmental sectors and scientific, research and professional bodies. How 
debida a otros factores, tales como una dieta más sana, más actividad física y menos tabaco (29).

\section{Sobre las organizaciones de carácter social}

Al representar a la industria de bebidas alcohólicas en debates políticos y en discursos sociales y públicos sobre el daño ocasionado por el alcohol, las organizaciones de carácter social buscarán asociaciones y actividades conjuntas con sectores gubernamentales y no gubernamentales, y organismos profesionales, científicos y de investigación. ¿Cómo deberían relacionarse estos diferentes sectores y organismos con estas organizaciones?

Para formular su política general sobre el alcohol, una amplia serie de diferentes departamentos gubernamentales a nivel nacional e internacional necesitarán recibir información y tener conversaciones con la industria de bebidas alcohólicas. Sin embargo, al desarrollar sus políticas, las instituciones de gobierno necesitan una información imparcial de los hechos para llevar a cabo una política eficaz del alcohol, y una información imparcial de los costes y beneficios de las diferentes opciones políticas. Debería señalarse que la información que reciben las instituciones gubernamentales por parte de las organizaciones de carácter social no es imparcial, y, por lo tanto, resulta inconsistente para lograr una política eficaz que reduzca el daño ocasionado por el alcohol.

Las organizaciones gubernamentales deben saber desempeñar sus obligaciones con respecto a la política del alcohol. Los estados europeos miembros de la Organización Mundial de la Salud, signatarios de la Declaración de Estocolmo del año 2001 sobre los Jóvenes y el Alcohol (30), han declarado que "las políticas de salud pública relacionadas con el alcohol necesitan ser formuladas por intereses de salud públicos, sin que existan interferencias de intereses comerciales."

Las organizaciones no gubernamentales con un papel específico en relación con la política del alcohol han sido encargadas de (31) "informar y movilizar a la sociedad civil con respecto a los problemas ocasionados por el alcohol, ejerciendo presiones para lograr un cambio de política y una implicación eficaz de las políticas a nivel gubernamental, así como de poner al descubierto las acciones perjudiciales de la industria del alcohol." Al desempeñar su papel, y respetar los puntos de vista de la sociedad civil, estas organizaciones específicas no gubernamentales harían bien en mantenerse completamente independientes y no asociarse ni relacionarse con organizaciones de carácter social. Cualquiera de los comunicados, diálogos o reuniones entre organizaciones no gubernamentales y organizaciones de carácter social, deberían ser transparentes y del dominio público.

A pesar de que ha habido un debate considerable acerca de las relaciones entre la ciencia de la salud pública y la industria de bebidas alcohólicas (32), el Cen- should these different sectors and bodies relate to such organizations?

In formulating their overall alcohol policies, a wide range of different government departments at the national and international levels will need to receive information from and have dialogue with the beverage alcohol industry. However, in developing their policies, government institutions need impartial information of the evidence for effective alcohol policy and impartial information on the costs and benefits of different policy options. It should be noted that the information government institutions receive from social aspects organizations is not impartial and is inconsistent with the evidence base for effective policy that reduces the harm done by alcohol.

Governmental organizations need to be cognisant of their obligations for alcohol policy. The European Member States of the World Health Organization signatories to the 2001 Stockholm Declaration on Young people and Alcohol (30), which stated that: "Public health policies concerning alcohol need to be formulated by public health interests, without interference from commercial interests".

Non-governmental organizations with a specific role with regard to alcohol policy have been charged with (31): "informing and mobilizing civil society with respect to alcohol-related problems, lobbying for policy change and effective implementation of policy at government level, as well as exposing harmful actions of the alcohol industry." In discharging their role, and in maintaining their respect with civil society, such specific non-governmental organizations would do well to remain completely independent of any association or partnership with social aspects organizations. Any communications, dialogues or meetings between non-governmental organizations and the social aspects organizations should be transparent, and placed in the public domain.

Although there has been a considerable debate about the relationship between public health science and the beverage alcohol industry (32), the International Center for Alcohol Policies was successful in recruiting a large number of scientists to contribute to the first five publications in its series on alcohol and society. Scientists are used by social aspects organizations to promote their standpoints, ideologies and viewpoints and to discredit scientific findings inconsistent with these standpoints. When the landmark publication Alcohol Policy and the Public Good was published, scientists were offered f2000 by the United Kingdom's Portman Group to "rubbish" the report and to permit their criticisms to be published with or without their names (33).

All independent scientists that are paid by or undertake work for the social aspects organizations 
tro Internacional para las Políticas del Alcohol tuvo el acierto de reclutar a gran número de científicos para que colaboraron en las cinco primeras publicaciones de sus series sobre el alcohol y la sociedad. Las organizaciones de carácter social utilizan a científicos para respaldar sus puntos de vista, ideologías e intenciones y para desacreditar las decisiones científicas en desacuerdo con las mismas. Cuando se publicó el importante documento "Política del Alcohol y el Bien Público", el Grupo Portman del Reino Unido ofreció a algunos científicos 2000 libras para "desechar" el informe y permitir que sus críticas fueran publicadas, con o sin sus nombres (33).

Todos los científicos independientes que colaboran o reciben un sueldo de las organizaciones de carácter social y la industria de bebidas alcohólicas deberían ser conscientes de su responsabilidad por hacer constar sus declaraciones de interés en sus publicaciones científicas. Científicos e investigadores en países de renta per cápita alta deberían considerar una responsabilidad ética no sacar provecho ni contribuir al éxito de las acciones de la industria de bebidas alcohólicas en mercados emergentes, en países de renta per cápita baja, que no suelen gozar de infraestructura, recursos y experiencia para reaccionar y regular de un modo efectivo las prácticas comerciales de las industrias de bebidas alcohólicas (34).

Babor ha propuesto lo siguiente (35): “Ha llegado el momento de declarar una moratoria para nuevos diálogos con las fuentes de la industria hasta que los científicos y la comunidad de la salud pública puedan llegar a un acuerdo sobre lo que son sus legítimos intereses, y sepan cómo evitar el comprometer nuestra bien ganada integridad. Ha llegado el momento de que nuestras publicaciones sobre la adicción y las asociaciones profesionales se pongan a la cabeza, examinen sus propias conexiones con las fuentes de la industria y adopten posiciones claras, pues son absolutamente imprescindibles códigos estrictos de ética que tengan en cuenta los proyectos y la comercialización de las bebidas alcohólicas. Si los patrocinadores de la industria no se adhieren a ellos, no puede haber un diálogo ni aceptarse el apoyo de sus terceras organizaciones. Aunque no nos corresponde entrar en conflicto o en controversia, tampoco tenemos obligación de entablar diálogo con organizaciones cuyas actividades de cara a la salud pública son inimitables. Dejemos que el debate público hable con claridad de los dos aspectos de un problema, en lugar de ver nuestros problemas manipulados por terceras organizaciones cuya programación sólo está aprobada por una de las partes. and the beverage alcohol industry should recognize their responsibility in stating their declarations of interest in their scientific publications. Research scientists in high income countries should also consider an ethical responsibility not to profit from or contribute to the beverage alcohol industry's actions in emerging markets in low income countries which often lack the infrastructure, resources and experience to respond to and effectively regulate the beverage alcohol industries' marketing practices (34).

Babor has proposed (35): "It is time to declare a moratorium on further dialogues with industry sources until alcohol scientists and the public health community can agree to what is in their legitimate interests, and how to avoid compromising our well-earned integrity. It is time for our addiction journals and professional societies to take the lead in examining their own connections with industry sources, and develop clear positions on the need for strict codes of ethics regarding the design and marketing of alcohol products. If industry sponsors do not adhere to them, then there can be no dialogue with, or support from, their third-party organizations. Although we do not by nature make it our business to engage in conflict and controversy, neither do we have a duty to engage in dialogue with organizations whose activities are inimitable to public health. Let the public debate clearly represent both sides of an issue, instead of having our issues managed by third party organizations whose agenda is approved by only one of the parties". 


\section{BIBLIOGRAFÍA / REFERENCES:}

(1) Anheuser-Bush Co. Inc. Annual Report 1997, p.3.

(2) Richter, J. (1998) Engineering of Consent: uncovering corporate PR (Dorset, UK, The Corner House).

(3) Grant, \& Litvak, J. Eds.Drinking Patterns and their Consequences London, Taylor \& Francis, 1998

(4) Edwards G et al. Alcohol Policy and the Public Good. Oxford, Oxford University Press, 1994

(5) Norstrom, T.\& Scog, O-J.Alcohol and mortality: methodological and analytical issues in aggregate analysis. Addiction 200196 (Supplement 1), S5-S17.

(6) World Health Organization. The ICD-10 Classification of mental and behavioral disorders. Geneva, World Health Organization, 1992.

(7) Houghton, E \& Roche, A.M.Eds.Learning about drinking London, Taylor \&Francis, 2001.

(8) Internationl Center for Alcohol Policies. Life skills education in South Africa and Botswana, 2000.www. icap. org. 9The Arnoldus Group. belgian.brewers@beerparadise.be

(10) Midford, R.\& McBride, N. Alcohol education in school. In Eds. Heather, N., Peters, T.J \& Stockwell, T. International Handbook of alcohol dependence and problems. Chichester: John Wiley \& Sons Ltd. pp 785804, 2001.

(11) Mc.Knight, A.J. \& Voas, R.B. Prevention of alcohol related road crashes. In Eds. Heather,N., Peters, T.j.\& Stockwell, International Handbook of alcohol dependence and problems. Chichester: John Wiley \& Sons Ltd. pp 741-770, 2001.

(12) Hill, L. \& Caswell, S. Alcohol advertising and sponsorship: commercial freedom or control in the public interest. In Eds. Heather, N., Peters, T.J. \& Stockwell, T. International Handbook of alcohol dependence and problems. Chichester: John Wiley \& Sons Ltd. pp823846, 2001.

(13) Grant, M.Ed. Alcohol and Emerging Markets London, Taylor \& Francis, 1998

(14) Grant, M.A New Force for Health. International Center for Alcohol Policies.http://www.icap.org/.

(15) Saxena, Alcohol, Europe and the developping countries. Copenhagen, WHO Regional Office for Europe, 1995 (document EUR/ICP/ALDT 94 03/CN 01/32).

(16) Peele, S. \& Grant, M. : a Health Perspective London, Taylor \& Francis, 1999

(17) The Beverage alcohol industry's social aspects organizations: A public health warning. London, Eurocare, 2002.

(18) Marketing alcohol for young people; Eurocare, London, 2001

(19) Hill, L. \&Caswell, S.Alcohol advertising and sponsorship: commercial freedom or control in the public interest. In Eds. Heather, N., Peters, T.J. \& Stockwell, T. International Handbook of alcohol dependence and problems. Chichester: John Wiley \& Sons Ltd. pp 823846, 2001.
(20) Van Dalen, W. Alcohol marketing in the Netherlands. Paper prepared for the WHO international technical meeting on Marketing and Promotion of Alcohol to Young People, Valencia, Spain, 7-9 May 2002.

(21) Hill, L. \& Caswell, Alcohol advertising and sponsorship: commercial freedom or control in the public interest. In Eds. Heather, N. Peters, T.J.\& Stockwell, T. International Handbook of alcohol dependence and problems. Chichester: John Wiley \& Sons Ltd. pp 823846, 2001.

(22) Dring, C \& Hope, A. \& Hope (2001). The impact of Alcohol Advertising on Teenagers in Ireland. Department of Health and Children, Dublin.

(23) Peele, S. \& Grant, M. Alcohol and Pleasure: a Health perspective London, Taylor and Francis, 1999

(24) Heath, D.B. Drinking Occasions: Comparative Perspectives on Alcohol and Culture London, Taylor and Francis, 2000

(25) Heather, N. Pleasures and pains. In Eds. Heather, Peters, T.J.\& Stockwell, T.International Handbook of alcohol dependence and problems. Chichester: John Wiley \& Sons Ltd. pp 5-14, 2001.

(26) Lemmens, P. Relationship of alcohol problems at the population level. In Eds. Heather, N.,Peters, T.J. \& Stockwell, T. International Handbook of alcohol dependence and problems. Chichester: John Wiley \& Sons Ltd. pp 395-412, 2001

(27) World Health Organization. World Health Report, 2002. Geneva: World Health Organization, www.who. int

(28) Towards a global alcohol policy: alcohol, public health and the role of WHO Jernigan D.H., Monteiro M., Room, R. \& Saxena S. Bulletin of the Woldd Health Organization, 2000, 78 491-499.

(29) Barefoot, J.C.Gronback, M.,Feaganes, J.R. Mac Pherson, R.S. Williams, R.B. \& Siegler, I.C. Alcoholic beverage preference, diet, and health habits in the UNC Alumini Heart Study Am J Clin Nutr 2002; 466-72.

(30) The Stockholm declaration on young people and alcohol 2001. Copenhagen, World Health Organization Regional Office for Europe.

(31) European Alcohol Action Plan 2002-2005. Copenhagen, World Health Organization Regional Office for Europe.

(32) Editorial Science and the drinks industry: cause for concern Addiction (1996) 91 (1), 5-9

(33) Rows over drinks industry attempt to rubbish alcohol report, Alcohol Alert, April 1995, 20, 2-3.

(34) Jernigan, D.H. \& Mosher, J.F. Permission for profits Addiction (2000) 95 (2), 190-191.

(35) Babor, T.F. Partnership, profits and public health Addiction (2000) 95 (2), 194-195. 